\title{
DISKUSSIE 3
}

Dr. J. van V. du Plessis, Welkom-Noord, vra krities:

Sê God werklik so? Enkele gedagtes oor Ferdinand Deist se boek: "Sê God so?".

Ferdinand Deist is professor in OT vakke aan Unisa en 'n vrugbare skrywer wat die afgelope tyd heelwat populêre werke laat verskyn het, bedoel vir die gewone leser en veral vir die Bybelstudie-studente. Dis is eenvoudig in maklike verstaanbare styl geskrywe en lees ook lekker.

As iemand so baie skrywe, verwag 'n mens dat daar een of ander tyd iets na vore sal kom wat sy Skrifbeskouing in duidelike lyne sal teken. Vir 'n skrywer oor Bybelse sake is dit van kernbelang. As jy sy Skrifbeskouing kan aanhoor, dan weet jy om óf onbevange te luister of te waarsku. En dit het ook gebeur met die werkie: Sê God so?

Die skrywer sê dat die oorsaak van die verskyning van die boekie enersyds 'n protes is teen die manier waarop die Bybel "misbruik" word. "Dit is 'n protes teen die geskarrel om alles 'Bybels' of 'christelik' te wil verklaar en so by te dra tot verwarring en wedersydse verkettering in die Naam van God". In die plek daarvan wil hy as pleidooi 'n alternatief voorstel wat hy nie as iets nuuts beskou nie maar wel as reeds eeue oud.

1. Protes teen die sg. byna godslasterlike "Bybelse eierdans" (p.3)

1.1 Deist mik veral na die politieke wêreld waar baie partye hulle standpunte uitlê as gegrond op 'n Bybelse leerstuk of 'n christelike beginsel. Vir apartheid word bv. die bewys gesoek in Gen. 10; die saamgooi van volkere word aan Paulus toegeskrywe wat sê die middelmuur van skeiding is afgebreek; die politieke bevryding refereer weer in die trek van Israel uit Egipte (p. 9-11). Elkeen ook die kerke, woeker met eie gekose tekste om sy waarheid daarmee te wil bewys. Die uiteinde is dat in die politiek agter God geskuil word, sodat die waarheid nie weer getoets kan word nie (p.5). God word in die mens se diens geneem - 'n God-aan-julle-kantgodsdiens. God word as't ware geskaak (p.6) en vanuit die verskillende loopgrawe word op mekaar geskiet.

1.2 'n Verdere probleem wat Deist het, is dat skrywers en sprekers telkemale verklaar "God wil ..." of "die Bybel leer ..." asof die Bybel vir elke politieke situasie 'n uitspraak op die rak het. So beroep skrywers hulle op apartheid as Bybelse geregtigheid (p.14) sonder om eksegeties na te gaan wat die Skrif met hierdie begrip bedoel. Andere beskrywe apartheid as sonde sonder om antwoord te gee op die vraag: wat is sonde? Sodanige uitsprake is vir Deist vaag (p. 15) en vol denkfoute. Die gelowige soek gedurig die wil van God, want die weë van God is hoër as ons weë. Paulus sê dan ook elders: "beproef wat die welgevallige wil van God is". Eindelik word hierdie uitsprake niksseggend ( $p$. 18), want daar word vanuit verskillende monde en vanuit verskillende uitgangspunte gepraat ( $p$. 17). 
Deist het hier onteenseglik 'n punt beet. 'n Mens het daaraan 'n broertjie dood dat gesaghebbend gesê word: volgens die Skrif staan die saak so, of die Bybel sê, terwyl nooit by die Skrif uitgekom word nie.

1.3 Deist erger hom verder vir die "voortdurende beheptheid met 'n christelike alles: skool, staat, wetenskap, politiek" (p. 19). Hierdie "spook" het 'n geskiedenis. Dit sou begin het by Konstantyn die Grote se bekering wat daarna die christelike godsdiens tot staatsgodsdiens verhef het. Deist sien dit as ' $n$ huwelik tussen die staat en die kerk wat op die bloedige kerstening van Europa uitgeloop het. Die draad volg sy gang langs Luther en Calvyn en het so "diep in die onderbewussyn ingekruip en deel van ons geword" (p. 21). Die hoogtepunt is by Kuyper bereik wat van "Christelik" 'n filosofie gemaak het. Deist noem dit "'n tradisie wat grys is" (p. 22) wat eindig by ' $n$ handeldryf met die Bybel om so agter Christus terug te val en wie dan durf kritiseer, word as 'n ketter genommer.

1.4 Nog 'n saak waarteen Deist dit het, is die term "christelik-nasionaal" Omdat alles christelik moet toegaan en ons nasionaal moet dink, moet die twee noodwendig saamgaan in een asem. Deist sien dit as deel van ons denke omdat ons gedurig in térme van strukture dink. So dink die een groep in die struktuur van apartheid met elk sy eie plek wat s.i. Bybels is. Net so is die integrasie-gedagte vir Deist ook Bybels en die vierkamer-parlement ook Bybels (p. 31).

Deist beweer dat die strukture-denke nie langs die weg van Skrifstudie gekom het nie, maar wel deur waarneming. Die vraag wat onwillekeurig by die leser opkom, is of Deist beleid met strukture vereenselwig. Deist se kritiek op die huidige politieke rigtingkoers in ons land is dan dat struktuurverandering nie die probleme gaan oplos nie. Die basiese vraag is "of die mense van daardie struktuur christelik is" (p. 33) m.a.w. die mens moet verander anders sal die aarde 'n plek van geweld bly. Nou verbeel ons dat "'n 'Bybels-gefundeerde' struktuur sal alles regstel"' (p. 34).

2. Deist se pleidooi om sake reg te sien, teen die agtergrond van 'n paar van sy uitgangspunte

Sy Skrifbeskouing

Volgens Deist ontstaan die Babelse spraakverwarring omdat die Skrif gebruik word sonder 'n bepaalde beskouing tov. wat die Skrif wel is. Dit is duidelik: Deist vergroot die spraakverwarring in plaas van om dit te besweer.

Deist stel dit kategories dat die Skrif 'n getuienisboek is waarin die geloofsoortuigings en geloofsuitinge van meer as duisend jaar opgeteken is, "'n duisend jaar waarin alles nie maar konstant en stabiel gebly het nie, maar waarin sienings oor God verander het, waarin mense nader aan die lig beweeg het" (p23). Die Skrif is dan 'n lewende getuienis van mense se worsteling om iets te begryp van God en God se worsteling om iets van Homself by mense te laat deurskemer. Nêrens word die beskouing egter in die boekie vanuit die Skrif bewys nie. 
Die Bybel word beskrywe as 'n bundel geskrifte wat in die tyd ontstaan het, tussen mense, deur mense "in die geloof in die bestuur van God". Hulle is doodnormale mense, allereers gelowige mense wat in die geloof gelewe, gewerk en gedink het. "Die produk van hulle gelowige denke en dade staan vir ons opgeteken in die Bybel, wat wonderbaarlik deur die millenia heen vir ons bewaar gebly het" (p.47).

Onmiddellik werp hierdie stelling allerlei vrae by die leser op. Hoe interpreteer Deist art. 3 van die N.G.B. Wat van die begrip kanon (art. 4 N.G.B.) as die Bybel slegs menslike geskrifte is? Waar staaf die Skrif self sy mening, want die Skrif getuig tog dat dit Gods Woord is (vgl. art. 5 N.G.B.)? Is Gods Woord dan nie Sy openbaring aan die mens nie soos art. 2 van die N.G.B. bely nie? Deist rep verder geen eksegetiese woord oor die klassieke woorde van Petrus oor die Skrifinspirasie in 2 Petr. $1: 21$ en díe van Paulus in 2 Tim. 3 : 16 nie.

Waarop loop Deist se Skrifbeskouing uit?

Skrifkritiek

Deist stel dat die Bybelskrywers eenvoudige haas ongeleerde mense was. "Hulle was geen gereformeerde dominees of uitgelese teoloë nie. Daarom kan 'n mens ook nie van die Bybel uitgewerkte denksisteme of teologiese verhandelinge verwag nie. Wat ons daar het, is brokstukke van getuienisse" (p. 48). Op dieselfde bladsy skryf Deist "ons het dus hier te make met 'n baie fragmentariese bundel getuienis van mense wat in hulle omstandighede gesoek het na die waarheid omtrent hulle lewe en God". Die Skrif het oor 'n tydperk van duisend jaar ontstaan en dit spreek vanself dat Bybelse getuies nie almal eenders sou praat nie en dink nie. Daarom sal die leser teenstrydighede vind. Die OT tyd is bv. 'n tyd van wyduiteenlopende denksisteme, want die Jode wat uit Egipteland getrek het was vol Egiptiese gebruike terwyl wat Kanaän later as heimat sou hê met 'n kanaänitiese lewensuitkyk sou worstel (p. 49.) Die Jode in die N.T. kom weer uit die Griekse era. So word die Skrif vir Deist geskrifte waarin die mense worstel om die wil van God vir hulle situasie te begryp en gee dit aan ons buitelyne en riglyne waarbinne ons ons worsteling sinvol kan voortsit ( $p$.51). Uiteindelik volg hieruit dat die Bybel bloot slegs kerklike geskrifte is (p. 49).

Dit hoef geen verdere verduideliking meer nie dat Deist die Skrif nivelleer en geen oog knip om dit aan Skrifkritiek te onderwerp nie. Ek meen alle skrywers van die Skrif was darem nie eenvoudige ongeletterdes nie. Ons verwys na Paulus wat 'n wetsgeleerde en Lukas wat 'n mediese dokter was.

\section{Humanistiese Skrifbenadering}

Deist sê "dis eintlik in hierdie proses van verantwoording dat die Bybel sy werklike rol vervul. Nadat ek in alle verantwoordelikheid my besluit geneem het, kan ek teenoor andere verantwoord waarom ek presies so en nie anders, besluit het ... Ek sal die Bybelgetuie ook deur die vuurproef van Christus - wat ook in my leef - moet stuur" (p. 53) 
Met hierdie aanhaling wil Deist die metode van Skrifgebruik aantoon. Hy onderskei tussen Skrifbewys en Skrifberoep. Eersgenoemde beskouing het dit asof die Skrif uit die hemel geval het as ewige waarheid wat nie deur mensehande geskryf is nie (p. 54). Vir Deist is die Skrif feilbaar en daarom moet nie by Skrifbewyse begin word nie; moenie vanuit die Skrif na die mens of situasie gaan nie, dws. Skriftuurplase in bepaalde konteks eksegetiseer, die diepere sin ontleed en daarna na die mens of situasie gaan nie, want ons het te doen met die gebrekkige getuienisse van mense. Skrifberoep wil met die situasie begin en ontleed en dan die hoed aan die kapstok van die Skrif gaan ophang. Daar word na die Skrif verwys om die Skrif as christelike tradisie te vergelyk met my oplossing.

Daarom redeneer Deist. (p. 56) dat Skriftuurlikheid nie 'n vertrekpunt moet wees nie, maar wel die eindpunt. "Skriftuurlikheid is nie 'n bewys nie, maar ' $n$ beroep".

Deist redeneer verder (p.55) dat as die leser uitgaan van die Skrifbewystradisie jy perspektief kan verloor op die situasie ... Daaruit kon ons aflei dat die situasie belangriker as die so sê die Here van die Skrif is. Skrifberoep maak erns met die situasie. Al wat van die Skrif in die situasie oorbly, is dat dit slegs 'n getuie is (p. 55) - "dis soos ek dit in alle eerlikheid en met vaste oortuiging sien" (p. 56).

Dit is voor die handliggend dat Deist 'n klap van die moderne teologie weg het waarin van die mens en die situasie na die Skrif geredeneer word. Die mens beslis, die mens tree op. Die Skrif is slegs 'n handperd, 'n getuienis van ander mense hoe hulle geworstel het om God te begryp. Die Skrif kan derhalwe slegs raad gee en kan nie gesagsvol optree nie, want dit het nie gesag in homself as openbaring van God nie. Dit kan nie apodikties optree nie, eis nie gehoorsaamheid aan Gods bevele op nie en is nie dwingend reël van die geloof nie. Die mens is daarenteen koning en moet self verantwoordelik besluit.

Deist sê trouens (p.57) "God beweeg in 'n magtelose gedaante tussen ons. Nie omdat Hy nie oor mag beskik nie, maar omdat $\mathrm{Hy}$ geen despoot is nie. God is geen dwingeland nie. God kom magteloos, verneder byna smekend tussen mense in en nooi hulle om in Hom te glo. Hy laat Hom selfs dié neé van mense geval. Hy dwing hulle nie. So ook Sy woord. Dis 'n alte menslike uitnodiging om deel te neem aan die gesprek".

Die invloed van die piëtisme kan hier nie weggeredeneer word nie. Piëtisme en humanisme is onteenseglig stalmaats.

Die vryheid van die mens

Die mens wil en moet vry beslis. Geen gesagsvolle mag van buite moet jou dwing nie. Slegs 'n beroep kan op hierdie gesag gemaak word.

Vrae wat hinder is die volgende: wat van die tweede gebod? God sê Hy is jaloers op Sy Naam. God in Sy almag en alomteenwoordige gesag moet nou buig voor koning mens. Skrik koning mens nie vir die wraak van God nie? (My kom die wraak toe, sê God). 
Die sonde wou God juis van die troon stoot (vgl. die paradyssonde, Gen. 3:5; die versoeking van Christus na Sy doop, Matt. $4: 8,9$; die versoeking aan die kruis, Matt. $27: 47$ ). Die paradyssonde nou weer in die boesem van die kerk!

Wat sê Deist in elk geval van Skrifgesag in die lig van die Skrif as getuienis?

Volgens Deist (p. 56) is die woord "gesag" hier 'n baie dubbelsinnige term omdat ons so baie gesagstrukture ken. Die gesag van die Skrif is nie patriargaal of despoties nie. Die Bybel is 'n dringende uitnodiging, nie 'n dwingende bevel nie. As ons die Skrif wil gebruik as outoritêre reëls (p. 57) of as magsvertoon, verydel dit die gesag van die Skrif, want dan word dit bygelowig of ongelowig gebruik.

"Want die Bybel se gesag setel nie in die boek en die gedruk. te letters nie, maar in God, byna onherkenbaar vermenslik, wat ons daarin te hulp snel" (p. 57). Die gesag van die Skrif is dan relatief: God het gewone mense aangestel om ons in gesprek by te staan. Ook hulle het hulle misverstande oor God gehad. Hulle hulp kom dus vanuit hierdie atmosfeer. Hulle was mense wat nie bang was om op verantwoordelike wyse met God te worstel en tot 'n punt van eie beslissing te kom nie. Nou moet die gelowige ook maar self deurworstel met die Heilige Gees by ons en dan lig gaan soek by hierdie skrywers hoe hulle lig gevind het en dan met jou konklusie korreleer (Tillich?) Daarin lê die gesag van die Skrif. Weereens geen sprake van Gods openbaring as Deist met die Skrif werk nie, vandaar die verwronge beeld oor die gesag van die Skrif.

Deist se pleidooi in die politieke situasie

Deist se Skrifbeskouing dat die Skrif slegs 'n getuienis is van die mens se worsteling met God se wil en sy oortuiging dat elkeen die Skrif aanhaal soos hy wil, laat hom dink dat Bybelaanhalings ons nie ' $n$ antwoord in ons politieke situasie sal gee nie (p.63).

Deist se eerste stelling: Vir ons in S.A. is belangrik "dat die interpretasie wat 'n gelowige aan die situasie gee, ' $n$ belangrike rol speel in de besluit wat hy in die ou end neem" (p. 63). Daar moet begin word waar die begin is, die situasie self (p. 64).

Deist se tweede stelling: Vanuit Christus leef ons as versoendes en dié moet sigbaar word. Deist sien in elke geval die versoening van Christus soos volg: "En God het sy versoeningswerk in absolute magteloosheid volbring uitgelewer aan die willekeur van mense en sonder legioene van engele" en "vir Hom was alle mense mense van God en geregtig op die liefde van God. Of hulle dit sou aanvaar, was nie Sy saak nie", en "God kom só onmagtig dat Hy Hom ook die 'nee' van 'n eenvoudige mens laat geval' (p. 67). My werk ten opsigte van my medemens moet dan nie wees asof my liefde vir Hom God die ja-woord sal ontlok nie, dog in die wete die mens is God se eiendom. Die vermenging van modernisme en die oue piëtisme kan in die denke van Deist nie geïgnoreer word nie.

Vanuit sy versoeningsvisie maak Deist die stelling dat die kerk op aarde al is wat christelik is (p. 68). Op aarde lewe die mens 
in 'n wêreld van sonde waar mag geld. Hoe moet die gelowige nou in die politiek optree as die kerk al plek is wat christelik is? (p. 69).

Volgens Deist kan die gelowige nie christelike eise aan die wêreld stel nie. Dan word die wêreld kerk gemaak. Die Christelike eis kan wel aan die gelowiges binne die kerk gestel word, maar nie in die politiek nie. Al wat die gelowige kan doen, is om soos sout en lig op te tree: uitleef van dit van God wat in hom woon. Die strukture kan nie verander word nie, maar kan wel die strukture met verdraagsaamheid vul. Kompromieë kan wel aangegaan word, maar dan moet gesorg word vir die beste bedingbare kompromie. Die idee van menslikheid en vergewensgesindheid moet in die politiek ingedra word.

Deist kom dan tot die gevolgtrekking (p. 71) dat ons in die kerk leef as verlostes en versoende mense. In die wêreld soos lammers onder wolwe. Al waarop ons kan staatmaak is die daadgetuienis, maar met geen dwangmag ten opsigte van jou christenskap - 'n deïstiese skeiding hemel en aarde, die vertikale en horisontale.

Deist wil dan hê dat dit die koers moet wees wat die regering moet inslaan'. Die politieke partye in die verlede het dan te veel ore uitgeleen aan die Skrifbewyse van kerke. Dit sou dan verwarring gestig het, want elkeen wil sy eie bewys dmv. die sg "skeppingsorde" en "God se wil" - verkoop. Die christen in die politiek moet homself liewer vergewis van die feitlike omstandighede (p.73), dws. empiries beweeg en dan met jou christelike gewete daarvoor gaan staan en vra: watter politieke oplossing kom die naaste aan "die nuwe aarde se leefwyse" - 'n utopia op die sondige aarde! Ook die regering moet empiries vanuit die situasie met slegs 'n Skrifberoep sy probleme polities oplos. Dan moet die sg. "christelike" struktuurdenke vergeet word. Die werklikheid moet ernstig bestudeer word en vanuit die politiese werklikheid na 'n antwoord soek. Al die verskillende kerke, afgesien van suiwerheid of onsuiwerheid, moet dan in een pot gegooi word en openlik getuig (p. 75).

Wat is die algemene indruk van Deist se boek?

Dit is byna 'n geloofsbelydenis van sy Skrifbeskouing, sy opvatting van die verlossing van Christus en van sy Godsbegrip. Deist het die Skrifkritiek aanvaar en daarmee die Skrif genivelleer tot 'n gewone boek met botsende beskouinge. Humanisme en piëtisme slaan telkemale deur. God word as't ware op die agtergrond gedwing met die mens in die hoofrol. Deïsme speel 'n groot rol in sy denke.

Wat makk Deist van die ondertekenigingsformulier? Wat is die belydenisskrifte vir hom werd? Het Deist by sy Sinode die nodige besware teen die Belydenisskrifte ingedien? Skynbaar speel dit geen rol in sy denke nie. Die vraag of Deist 'n positiewe bydrae in die oplossing van ons politieke probleme gelewer het, kan betwyfel word. 